IZA DP No. 7252

Labour-Market Outcomes of Older Workers in the Netherlands: Measuring Job Prospects Using the Occupational Age Structure

Nicole Bosch

Bas ter Weel

February 2013 


\title{
Labour-Market Outcomes of Older Workers in the Netherlands: Measuring Job Prospects Using the Occupational Age Structure
}

\author{
Nicole Bosch \\ CPB Netherlands Bureau for Economic Policy Analysis \\ Bas ter Weel \\ CPB Netherlands Bureau for Economic Policy Analysis, \\ Maastricht University and IZA
}

Discussion Paper No. 7252

February 2013

IZA

P.O. Box 7240

53072 Bonn

Germany

Phone: +49-228-3894-0

Fax: +49-228-3894-180

E-mail: iza@iza.org

Any opinions expressed here are those of the author(s) and not those of IZA. Research published in this series may include views on policy, but the institute itself takes no institutional policy positions. The IZA research network is committed to the IZA Guiding Principles of Research Integrity.

The Institute for the Study of Labor (IZA) in Bonn is a local and virtual international research center and a place of communication between science, politics and business. IZA is an independent nonprofit organization supported by Deutsche Post Foundation. The center is associated with the University of Bonn and offers a stimulating research environment through its international network, workshops and conferences, data service, project support, research visits and doctoral program. IZA engages in (i) original and internationally competitive research in all fields of labor economics, (ii) development of policy concepts, and (iii) dissemination of research results and concepts to the interested public.

IZA Discussion Papers often represent preliminary work and are circulated to encourage discussion. Citation of such a paper should account for its provisional character. A revised version may be available directly from the author. 


\section{ABSTRACT}

\section{Labour-Market Outcomes of Older Workers in the Netherlands: Measuring Job Prospects Using the Occupational Age Structure ${ }^{*}$}

This paper analyses changes in job opportunities of older workers in the Netherlands in the period 1996-2010. The standard human capital model predicts that, as a result of human capital obsolescence, mobility becomes more costly when workers become older. We measure and interpret how changing job opportunities across 96 occupations affect different age and skill groups. Older workers end up in shrinking occupations, in occupations with a lower share of high-skilled workers, in occupations facing a higher threat of offshoring tasks abroad, more focus on routine-intensive tasks and less rewarding job content. This process is not only observed for the oldest group of workers, but for workers aged 40 and above. Observing older workers in declining occupations is to a large extent a market outcome, but declining job opportunities in terms of less satisfying working conditions and job tasks and content could potentially raise incentives to retire early.

JEL Classification: J24, J60

Keywords: older workers, employment, occupational mobility

Corresponding author:

Bas ter Weel

CPB Netherlands Bureau for Economic Policy Analysis

P.O. Box 80510

2508 GM The Hague

The Netherlands

E-mail: b.ter.weel@cpb.nl

\footnotetext{
* We would like to thank an anonymous referee, Lex Borghans, Rob Euwals, Paul de Beer, Jan van Ours and Trudie Schils for comments on an earlier draft of this paper and Andrea Jaeger for excellent research assistance.
} 


\section{Introduction}

The labour-market position of older workers is of special economic and social interest because many advanced economies, including the Netherlands, are faced with an ageing population and higher life expectancy. Policy measures have been taken to give workers incentives to stay in the labour market and to postpone retirement. This way the population utilizes its human capital in a better way and the financial burden of an ageing population should become sustainable. ${ }^{1}$

One of the main challenges for older workers is to keep applying their human capital in a productive way. As a result of ongoing technological change and depreciation of human capital over the lifecycle both the value and the stock of human capital decline (Ben-Porath, 1967 and Rosen, 1975). Especially non-neutral technological change over the past decades, recently augmented by the outsourcing and offshoring of tasks, is eroding the value of human capital of particular types of workers, also in the Netherlands (e.g., Akçomak, Borghans and Ter Weel, 2011 and Ter Weel, 2012). An important question is how these changes in the value of human capital affect job opportunities of older workers. In particular, as some occupations rise and other decline, which age and skill groups are positively and negatively affected by these developments? And, when does this give rise to labour-market problems?

Our research contributes to the knowledge about labour-market opportunities of older workers in the Netherlands by measuring and interpreting the patterns of occupational mobility of workers in the period 1996-2010. The idea of this approach is that mobility becomes more costly with age, even when we neglect institutions (e.g., Jovanovic, 1979a, $1979 \mathrm{~b}$ and Altonji and Shakotko, 1987). ${ }^{2}$ Workers develop occupation-specific human capital as they remain working at the same firm for a while. Firms demand a certain combination of skills, which makes workers more productive in these particular firms but reduces the value of human capital outside these firms (e.g., Lazear, 2009). When technological change makes some of the skills within occupations obsolete, older workers face an incentive not to exit such occupations, while younger workers face an incentive not to enter them (e.g., Weinberg,

\footnotetext{
${ }^{1}$ In the Dutch policy discussion De Economist has contributed to the discussion of future labour-market developments in Europe with among others a special issue labelled "ageing workforces" in 2011 (De Economist, vol. 159, no. 2; Vandenberghe, 2011) and Van Ours (2009) for an analysis of declining productivity when workers become older. See Broer (2001), Bettendorf et al. (2011) and Heijdra and Mierau (2011) for assessments of the sustainability of the welfare state.

${ }^{2}$ Deelen (2012) presents wage-tenure profiles for Dutch workers in the period 1999-2005. Using administrative data, she finds that these profiles are relatively steep compared to other countries. Also industries with high returns to tenure appear to have a high share of older workers and low levels of job mobility. Borghans et al. (2007) obtain that high wage growth is related to low job flows for older workers in the Netherlands.
} 
2001 and Violante, 2002). ${ }^{3}$ The reason for older workers not to exit the occupation is that wage losses have to be incurred because the specific bundle of skills they have developed cannot be transferred (e.g., Heckman and Scheinkman, 1987) and because reinvestment in skills is not worthwhile anymore because of the too short time horizon to reap the benefits from such efforts (e.g., Saint-Paul, 2009). At the same time, employers react by curtailing hiring in these occupations because demand is falling. This implies that the mean age of an occupation's workforce will rise as its employment declines (e.g., Autor and Dorn, 2009). At the same time, older workers face lower incentives to invest in their human capital (Schils, 2005). So, a rising average occupation-age is a signal of low mobility and decline.

This pattern is not necessarily a problem because occupations rise and fall. Town criers and typists are not observed anymore and webpage architects are only in existence since the 1990s. It becomes problematic if technological change alters the job tasks in such a way that the value of a worker's human capital drops substantially. Recent evidence suggests that the demand for job tasks such as bookkeeping, clerical work and repetitive production tasks has been eroding rapidly with the advance of information and communication technology (e.g., Autor, Levy and Murnane, 2003 and Acemoglu and Autor, 2011). A core feature of this evidence is the distinction between worker skills and job tasks. This distinction is important when the assignment of skills to tasks is evolving over time, because the set of tasks demanded in the economy is altered by technological change. For older workers with no incentive to move to other occupations, economic obsolescence of their human capital leads to lower levels of productivity and the desire to retire earlier rather than later because job satisfaction falls too (Kotlikoff and Ghokale, 1992). This puts forward a problem if these workers are forced to remain in the labour market for a longer period of time, while at the same time many of the productive tasks they used to perform have either been automated or are now performed abroad.

We focus on employment changes among occupations in the Netherlands in the period 19962010. It has proven notoriously difficult to establish how age itself affects labour productivity, not only because productivity is highly individual and occupation specific, but also because of the difficulty to distinguish age, cohort and selection effects. ${ }^{4}$ Our empirical

\footnotetext{
${ }^{3}$ Bartel and Sicherman (1993), Peracchi and Welch (1994) and Ahituv and Zeira (2005) argued that problems to cope with technological change and new technologies adequately, might force older workers to leave employment and push them into early retirement or unemployment.

${ }^{4}$ See e.g. Euwals, De Mooij and Van Vuuren (2009), De Hek and Van Vuuren (2010) and Van Ours and Stoeldraijer (2011) for reviews of the theoretical and empirical literature.
} 
strategy of the occupational age structure follows the recent analysis of Autor and Dorn (2009) for the United States. They measure for 330 occupations how changing job opportunities affect different age and skill groups. We first document a relationship between changes in occupational size (as a share of total employment) and shifts in the age distribution of the occupation's workforce for 96 occupations. The estimates show that older workers are overrepresented in declining occupations. We continue to explain this pattern by investigating differences in educational requirements, the effects of technological change and offshoring, the job content in terms of the tasks that have to be carried out across different occupations and by measuring differences in the quality of work. We find that workers in ageing occupations have on average lower levels of education, are more vulnerable to threats of offshoring, carry out more routine-intensive and less abstract job tasks. Technological change, measured by computer-intensity, does not seem to impact older and younger workers in a different way. The same seems to be true for the quality of work, which does not seem to decline with age once we control for changes in employment shares.

From a policy point of view these results are of interest as well. The Dutch government has designed an agenda to foster the employment of older workers. On the one hand, early retirement has become less attractive, which has increased the average retirement age over the last decade. On the other hand, measures are taken to provide sustainable employment over the lifecycle. If workers face incentives to work longer, it has to be attractive to stay in the labour market for a longer period of time. Our estimates suggest that the job prospects of older workers are not necessarily such that they would be willing to stay in the labour market for a longer period of time. In addition, the decline in job opportunities starts already in the age group of 40-year old workers.

This paper proceeds as follows. In Section 2 we discuss the main idea and the related theoretical literature. Section 3 presents the most salient details about the data and presents construction the data set. In Section 4 we show a descriptive analysis of labour-market developments in the Netherlands. In Section 5 we present our empirical strategy and show the estimation results. Section 6 concludes and points at the policy relevance of our work.

\section{Background}

Ben-Porath (1967) extends Becker's human capital theory (Becker, 1962) by building a lifecycle model of human capital. This model includes investments and depreciation and delivers wage and productivity profiles over the life-cycle. Agents are assumed to be risk-neutral, 
maximizing the present discounted value of their lifetime earnings. The present discounted value of earnings from the beginning of the career is given by

$$
Y(0)=\int_{0}^{X} e^{-r x} y(x) d x
$$

where $x$ is age, $X$ the length of the career, $r$ the real interest rate and $y(x)$ the real earnings at age $x$. In this simple model, workers do not change occupations and new technologies do not arrive.

Weinberg (2001), Violante (2002) and Ahituv and Zeira (2005) extend this approach to study the adoption of new technologies by different skill groups at different points in time. Assume for simplicity that the economy consists of two occupations, old $(O)$ and new $(N)$. There are two forms of human capital, one for working in the old occupation and one for the new occupation. People invest in human capital in the occupation they are in. Earnings in occupation $i$ at age $x$ are $y_{i}\left(x, s_{i}(x), h_{i}(x)\right)$. In this expression, $s_{i}(x)$ denotes the share of time devoted to investment in human capital in occupation $i$ at age $x$. This will be used by the worker to maximize lifetime earnings. The term $h_{i}(x)$ denotes the current level of human capital in occupation $i$ at age $x$, which is determined by the optimal path of investment. If the worker switches from the old to the new occupation at age $q$, the present discounted value of his earnings (when he starts working) is equal to

$$
Y(0, q)=\int_{0}^{q} e^{-r x} y_{O}\left(x, s_{O}(x), h_{O}(x)\right) d x+\int_{q}^{X} e^{-r x} y_{N}\left(x, s_{N}(x), h_{N}(x)\right) d x
$$

Human capital develops according to $\dot{h_{l}}=f_{i}\left(s_{i}(x), h_{i}(x), \delta_{i}\right)$. The function $f_{i}(\cdot)$ is increasing in both $s$ and $h$ and decreasing in the depreciation rate $\delta_{i}$.

The main implication is to show whether a worker switches from the old to the new occupation. Because the old and new occupation require different types of human capital (by assumption and to make the story easy to comprehend), experience in the old occupation determines the initial levels of human capital with the new technology. The transferability of human capital from the old to the new occupation is likely to be imperfect. Older workers have accumulated human capital through their experience with the old technology and part of this human capital will be lost when a worker switches to the new occupation. By contrast, younger workers have only little investments in the old occupation and lose much less by switching to the new occupation. This implies that $h_{N}(q)=h_{O}(q)^{\gamma}$, with $\gamma<1$. In other words, workers who have a high level of human capital in the old occupation have a 
comparative disadvantage in the new occupation. Older workers, who will tend to have higher skill stocks in the old occupations, will experience greater depreciation rates when switching occupations. They are more likely to be observed working in the old occupation, which are contracting in terms of employment. Thus, under imperfect transferability of human capital across occupations, younger workers are more likely to switch occupations or enter the labour market in new occupations, which tend to be the growing occupations.

A second implication is that the higher rate of depreciation of human capital in the old occupation could hollow out core parts of the job, making them less attractive and making it less attractive to postpone retirement. Autor, Levy and Murnane (2003) have shown for example that the demand for bookkeeping and clerical work has plummeted because of computerization of these job tasks. ${ }^{5}$ Assume an occupation consists of two bundles of distinct tasks, 1 and $2 .{ }^{6}$ Workers have a productivity in both, which varies by occupation and age. Occupations combine the two tasks in different ways. Now, $s_{i}$ is the total time investment in both skills, say $s_{i}=\theta s_{i, 1}+(1-\theta) s_{i, 2}$, with $0 \leq \theta \leq 1 ; \theta$ varies between occupations. Assume: $\theta_{O}>\theta_{N}$.

As a result of technological change, task 1 will be taken over by machines or capital equipment and immediately render that part of the worker's human capital obsolete. This decreases the value of a worker's stock of human capital in both occupations (the old and the new occupation) but more so in the old occupation because of the larger weight on task 1 in the old occupation $\left(\theta_{O}>\theta_{N}\right)$. So, the older the worker and the more weight on task 1 before technological change, the larger the depreciation rate. The implication is that skill transferability becomes even lower and the remaining work requires more practice and work experience than skill and becomes more routine work (e.g., Neal, 1995, Poletaev and Robinson, 2008 and Kambourov and Manovskii, 2009). Older workers with relatively large investments in the obsolete type of human capital become stuck in these occupations and younger workers are put off to enter these occupations $(\gamma \ll 1) .^{7}$ Weinberg (2001) finds support for this effect, since $\gamma$ seems to be lower for high-school graduates, who perform less advanced tasks, relative to college graduates.

\footnotetext{
${ }^{5}$ See e.g., Borghans and Ter Weel (2006) and Akçomak, Borghans and Ter Weel (2011) for a recent analysis for the Netherlands and Acemoglu and Autor (2011) for an overview of the literature.

${ }^{6}$ Heckman and Scheinkman (1987), Gathmann and Schönberg (2010) and Acemoglu and Autor (2011) develop more general models of task bundles.

${ }^{7}$ Lazear (2009) and Gathmann and Schönberg (2010) develop this argument in more detail.
} 
Before we present empirical evidence for the Netherlands, consistent with these two implications, we first show how we built a dataset capable of analyzing these implications across occupations in a careful and robust manner.

\section{Data}

Our unit of analysis is the occupation. We aggregate all information from the several microlevel databases to the three-digit occupational level and weigh by occupation size in the empirical analyses. We use the International Standard Classification of Occupations (ISCO), which is a tool for organizing occupations into a clearly defined set of groups according to the tasks and duties undertaken in the job.

Tables A1 and A2 in the appendix show the definitions and data sources of all variables constructed for the purpose of the empirical analysis as well as the means and standard deviations.

\subsection{Employment}

We use the Enquête Beroepsbevolking (EBB) to define employment and organize occupations. The number of occupations for which we have obtained all relevant information and which cells contain at least 75 workers is equal to 96 . The total number of three-digit occupations in the EBB is 112. This set contains 14 occupations with fewer than 75 employees. $^{8}$ In addition, there is one occupation for which there are no task data available (ISCO 11 Armed forces). Finally, one occupation (ISCO 410 General and keyboard clerks) does not contain consistent employment information.

For each occupation we measure its employment size and the age distribution in 1996-1999 and 2007-2010. We pool these years together to obtain a larger sample of workers within each occupational cell. The differences between the two periods show how the employment shares and composition of workers between occupations change over time.

Figure 1 presents the change in the size of the four age groups we consider. We have split the sample into four age groups. The very young workers (16-24) and very old workers (60-64) are the smallest groups in our data. The employment share of the very young workers is more or less constant in the period 1996-2010 at around 13 percent, whereas the employment share

\footnotetext{
${ }^{8}$ These are ISCO $348,521,614,700,711,732,733,744,800,811,813,816,822$ and 834 . If we in addition exclude those occupations whose cells contain less than 100 workers $(212,230,613,615,812,814$ and 820) the results remain similar.
} 
of the very old workers rises substantially (from 2 to 5 percent). This rise is most likely due to institutional reforms in the 2000s, which made early retirement (before the age of 65) less attractive. The largest groups in our data are the prime-age workers. We split this group into two: the younger workers (aged 25-39) whose share declines from 45 to 32 percent and the older prime-aged workers (40-59) whose share rises from 40 to almost 50 percent. On average the workers in our sample become 2.8 years older in the period 1996-2010.

Figure 2 shows to what extent workers in different age groups have been employed in either occupations that gain employment or occupations that have been shrinking in the period 1996-2010. The horizontal axis discriminates between the four age groups and the vertical axis measures the changes in employment shares. The sum of both the shrinking and growing occupations is zero because we document changes in employment shares. For example, the employment share of the youngest age group has increased by 2.9 percent in growing occupations, whereas it is been declining by 1.2 percent in shrinking occupations. The same pattern is observed for workers in the age bracket 25-39. Their overall employment share has declined but it has been declining stronger in shrinking occupations (13.5 percent). The share of the older age groups has increased and this development seems to be stronger for shrinking occupations: the employment shares of workers $>40$ years old has been rising in shrinking occupations. The trends in this figure suggest that not only the oldest workers are employed in declining occupations, but that also the older share of the prime-aged workers (aged 40-59) in the Netherlands seems to be less job opportunities.

\subsection{Other variables}

To be able to explain changes in the age composition of employment in the Netherlands we construct a number of variables that serve as explanatory covariates in the regression analysis. Next to employment information, there are four types of measures that help explain changes in the age composition of occupations.

First, we measure differences in the average level of education across occupations. We do so by constructing a variable measuring the share of workers with higher levels of education in each occupation. This is defined as those workers with at least higher vocational levels of education. There is substantial heterogeneity in terms of the education variable in our sample. The average share of higher educated workers equals 29 percent. However, there are occupations in which none of the workers has completed higher education, whereas in others 99 percent has a higher level of education. The job prospects for workers in occupations with 
higher shares of educated workers seem to have improved over the period 1996-2010. Table 1 reports simple correlations between all variables used in the analysis. The correlations suggest (in a causal interpretation) that occupations in which more educated workers are employed have increased in terms of employment shares and have experienced a net inflow of younger workers.

Second, we measure technological change by the importance of using computers to perform the job and by the threat of offshoring. Computerization is not available in Dutch databases. That is why we use an indicator for computer usage from the ONET database, which is available for all US occupations. We assume that computerization of work in the United States is similar to that in the Netherlands. The measure documents occupational experts' assessment of how important it is for workers to use computers to programme, write software, set up functions, enter data, or process information. The scores range from 1 to 5 . All occupations seem to be using computers but the importance differs across occupations, as Table A2 suggests. The correlation coefficients in Table 1 suggest that there is no significant correlation between computerization and changes in employment or age composition. We also build an offshoring indicator that measures embodied imported inputs for each industryoccupation cell. The offshoring indicator is based on a proxy of the share of non-energy imported intermediate goods in total non-energy intermediate inputs, developed by Akçomak, Borghans and Ter Weel (2011). The indicator measures the amount of imported inputs needed to produce one unit of output taking all embodied imports into account. This way we are able to measure which occupations are most under pressure from offshoring. The correlations in Table 1 suggest that the threat of offshoring seems to be related to employment and age composition. Occupations that have declined in terms of employment shares seem to be more affected by offshoring. At the same time, there is a correlation with the age composition of employment as well: occupations with higher shares of older workers seem to have been more affected by offshoring.

Third, we measure the importance of job tasks across occupations. Following the research of Autor, Levy en Murnane (2003), Autor, Katz en Kearney (2006) and Autor and Dorn (2009), we construct measures of routine task intensity and abstract tasks in all occupations. Technological progress seems to have made routine tasks less important, as these tasks are to a great extent taken over by computers (e.g., Autor, Katz and Krueger, 1998). At the same time, more abstract tasks seem to have become relatively more important. Again we apply US data sources to measure this. The measures are taken from the Dictionary of Occupational 
Titles and its successor ONET. We standardize the task measures and use employment shares in 1996-1999 as weights.

Routine-task intensity, $r t i$, for each occupation is measured by the log of the ratio of technical skills and basic skills: $r t i=\ln \left(\frac{\text { technical skills }}{\text { basic skills }}\right)$. This is similar to how Autor and Dorn (2009) define routine-task intensity of US occupations. The intuition behind this measure is that basic skills facilitate learning or more rapid acquisition of knowledge and include capacities such as reading, writing and logical thinking. Technical skills are capacities used to design, set-up, operate, and correct malfunctions involving application of machines or technological systems. Examples of technical skills are installation, repairing and programming. The more important the latter relative to the former, the more routine tasks the performance of an occupation demands. The correlations in Table 1 reveal a relatively strong relationship between this measure and the share of older workers in an occupation. At the same time, routine-task intensity seems to be related to a higher threat of offshoring, lower average levels of education and less technological change.

The indicator for the importance of abstract task is based on a distinction between routine and non-routine tasks and a distinction between manual, cognitive and analytic or interactive tasks (as in Autor, Levy and Murnane, 2003). It is the sum of the performance of tasks concerning direction, control and planning $(d c p)$ and tasks as general education development and mathematics (math) in an occupation: abstract $=\sum(d c p+$ math $)$. The correlation coefficients of an occupation's abstract-task intensity seem to run in the opposite direction compared to the routine-task intensity measure (see Table 1). This seems consistent with the evidence documented for in the United States (Autor, Levy and Murnane, 2003) and more recently for European countries as well (e.g., Goos, Manning and Salomons, 2009).

Finally, we construct an indicator of the quality of work. This is a measure of the effortreward imbalance that measures the quality of work. We apply the measure developed and validated by Siegrist et al. (2006). Again we have to merge other data sources to the EBB to construct this measure. This time our source of information is the 2004 wave of Survey on Health and Retirement in Europe (SHARE). As a result of our approach to study three-digit occupations, some cells have only a few observations. To deal with the problem of small sample sizes, we combine the information from the Dutch and the German samples to construct our measure of effect-reward. The measure is the ratio of the mean of effort and reward indicators. The effort inputs are physically demanding work, time pressure and little 
freedom to carry out the work, poor prospects and job security. The reward inputs consist of the opportunities to develop skills, support and recognition of work and job satisfaction: the higher the value of the ratio, the lower the quality of work in an occupation. The correlations in Table 1 suggest a significant relationship between this indicator and the share of older workers as well as fewer high-educated workers, higher routine-task intensity, lower computer use and higher offshoring threats. ${ }^{9}$

\section{Descriptive analysis}

Before we present a set of regression results, we discuss the heterogeneity across occupations in more detail. First, Table 2 presents the five occupations that have grown most rapidly as well as the occupations that have been shrinking most rapidly over the period 1996-2010. Growth and decline are measured by changes in employment shares. Remarkable is the falling employment share of administrative occupations, such as clerks. This fall is consistent with the trends presented in Autor, Levy and Murnane (2003) in the United States, Goos, Manning and Salomons (2010) and Michaels, Natraj and Van Reenen (2010) for the European Union and Ter Weel (2012) for the Netherlands. In contrast, the employment shares of high-skilled occupations, such as business professionals, architects and related professionals, have grown, which is consistent with the US-evidence documented in Autor, Katz and Kearney (2006) and the UK-evidence in Goos and Manning (2007). The same is true for service sector workers, such as personal care workers and salespersons. This observation is in line with a possible complementarity between high and low-skilled occupations, as observed recently by Autor and Dorn (2013) for the United States. Hence, changes in employment shares in the Netherlands in the period 1996-2010 seem to be similar to the changes observed in other countries.

The next two columns of Table 2 present the average age of workers in these ten occupations and the initial employment shares. The figures do not show a clear pattern in terms of these two variables. The occupations that grow (shrink) the fastest in terms of employment shares are not the youngest (oldest). Also the initial employment shares do not seem to predict growth or decline.

To investigate these patterns for all 96 occupations in our database, Figure 3 shows the correlation between the change in the average age of workers in an occupation and the

\footnotetext{
${ }^{9}$ The assumption is that German and Dutch occupations are similar with respect to the inputs used to construct this variable.
} 
change in the employment share of the same occupation. The size of the bullets represents the initial employment share (1996-1999) of the occupations in total employment. The slope of the linear regression line suggests a negative relationship between changes in employment shares and the average age of workers in an occupation, which is consistent with the correlation coefficients in Table 1. Occupations that have experienced a 1 percent decline over time seem to have seen a rise in the average age of almost 2 years. ${ }^{10}$ An example of such an occupation is "administrative associate professionals", which is the occupation in the top left corner of Figure 3. Its employment share decreased by 1.15 percent and the average age increased with almost 4 years. This occupation provides a good example for how computerization seems to have made clerical job tasks redundant. Groot and De Grip (1991) and Autor, Levy and Murnane (2002) present case studies in which the same trend is observed for similar types of front and back-office occupations in the financial sector. If we exclude this occupation, the slope of the regression line becomes steeper (from -1.95 to $-2.19)$ at a similar level of significance.

Finally, the six panels of Figure 4 show changes in the average workers' age on the vertical axis and measures of education, technology, tasks and job quality on the horizontal axis for each occupation. A linear regression line is also presented in each of the figures. A positive slope indicates that an increase in education, technology, task content or job quality is correlated with an increase in the average age of workers in an occupation. This is true for the offshoring indicator, the routine-task intensity of occupations and the effort-reward balance. This suggests that occupations more vulnerable to competition abroad, which have more routine tasks and which require relatively more effort have grown older. That is, the average age in occupations subject to these trends has increased. At the same time, these occupations have a relatively low share of higher educated workers, less computerization and a lower intensity of abstract task performance.

The routine-task intensity scores of two occupations are informative to compare. Let us consider higher skilled teaching professionals and machinery mechanics and fitters. The former has the lowest score on routine-task intensity (most left bullet) and the second the highest score on routine-task intensity (most right bullet) in the fourth panel of Figure 4. At the same time, the average age of workers in higher skilled teaching professionals has decreased by 2 years, whereas average age of machinery mechanics increases by 2 years in

\footnotetext{
${ }^{10}$ The regression coefficient is significant at the 1 percent level.
} 
the period 1996-2010. The outcomes on the other measures are also different between these two occupations. Whereas the share of high-skilled workers (first panel) is 92 percent for teaching professionals, it is only 4 percent for machinery mechanics and fitters. Teaching professionals score high (4.1 on a scale from 1-5) on our measure of the importance of using computerized equipment (second panel), while the average importance for mechanics equals 2.2. Not surprisingly, teaching professionals have one of the lowest scores (0.05) on the offshoring indicator (third panel), whereas machinery mechanics and fitters score somewhat above average (0.23). The abstract task indicator (fifth panel) is also higher for teaching professionals ( 7.5 on a scale from $0-20)$ relative to the value for machinery mechanics and fitters (2.5). The scores on effort-reward imbalance (sixth panel) show higher values for machinery mechanics and fitters. This suggests that their average level of job quality is likely to be lower relative to teaching professionals.

\section{Strategy and estimation results}

We continue by investigating these patterns in a more formal way. To do so, this section reports two sets of estimates. First, we report estimates on the relationship between changes in occupational size and shifts in the age composition of an occupation's workforce. Second, we show the estimated effects of technological change, job tasks and health on the age composition. The estimated coefficients are reported in Table 3. Each reported coefficient is the results of a separate regression.

\subsection{Basic estimates}

We first show the relationship between changes in occupational size (relative to total employment) and shifts in the age composition of the occupation's workforce:

$$
\Delta A_{j}=\alpha+\beta_{1} \Delta E_{j}+\varepsilon_{j}
$$

where $A_{j}$ is the mean age of workers in occupation $j$ or the share of workers in a certain age bracket within occupation $j . E_{j}$ is the share of an occupation in total employment in the Netherlands. The two points in time we compare are 1996-1999 versus 2007-2010. We always weight by occupational size. Because of the imperfect transferability of skills, we expect older workers to be overrepresented in declining occupations.

The first row of Table 3 shows the results. The first coefficient suggests that the average age of workers in occupations in which employment has declined by one percentage point has 
become 0.95 years higher relative to the mean. The next four columns decompose this number by four age groups. The coefficients in these columns add up to the average change reported in the first column. The coefficients suggest that age increases in contracting occupations are driven by a falling employment share of younger workers ( $<40$ years old) and rising employment shares of older workers. Especially the very young workers seem to enter growing occupations, as the coefficient of 2.29 is large and statistically significant. The bottom row of Table 3 shows changes in the means of the overall change in age (2.78) and by age group. These changes are in accordance to the changes reported by Statistics Netherlands (www.statline.nl). Because of the relatively small numbers of observations in the 96 occupations and across age groups, we are unable to split the sample into more detailed age brackets.

\subsection{Technology, tasks and the quality of work}

Next, we add measures for occupational change based on education, the task content of jobs, measures for job quality based on the effort-reward imbalance in occupations and measures for technological change (computerization and offshoring), as discussed in Section 3:

$$
\Delta A_{j}=\alpha+\beta_{1} \Delta E_{j}+\beta_{2} T+\varepsilon_{j}
$$

where $T$ indicate the measures of education, technology, job quality and tasks as defined in Table A.1 in the Appendix. The results of this exercise are reported in Table 3. We report the coefficients for both $\beta_{1}$ and $\beta_{2}$. The coefficients on $\beta_{1}$ remain qualitatively and quantitatively more or less similar to the ones reported in the first row of Table 3.

The second row of Table 3 shows that in occupations that have a higher share of high educated workers, 25-39 year old workers are overrepresented and 40-59 year old workers are underrepresented. The coefficients for the youngest and oldest group of workers could be subject to selection, since higher educated workers enter the labour market later and also retire later. It is also remarkable that within the group of prime-aged workers, the workers above 40 are overrepresented in declining occupations and occupations that require less education. On average, these workers still have to work for at least 15 more years, some of them for at least 25 years.

The next set of two estimates shows the effects of the technology indicators on changes in the age composition of occupations. There does not seem to be a statistically significant correlation between the importance of computer usage across ages and changes in the age 
composition of employment, except for the oldest group of workers. In addition, the impact of computerization on the point estimates is also low. This is consistent with earlier estimates for the United Kingdom (Borghans and Ter Weel, 2002) and the United States (Friedberg, 2003). In these countries, there is also no statistically significant and economically large effect of age on computer use, except for the oldest group of workers. The estimates for the offshoring indicator do not show an overall statistically significant correlation with age changes, but are negative for the two youngest age groups and for the oldest; the estimates are positive for the 40-59 year old workers. These estimates suggest that occupations whose dependence on foreign competition is one standard deviation higher than the mean seem to have experienced a 2.2 percent increase in the share of 40-59 year old workers at the expense of the other age groups. Apparently, this group of workers is relatively more often working in occupations under threat of offshoring, which is consistent with the findings reported by Autor and Dorn (2009) for the United States.

The next set of two estimates relate changes in the age distribution of occupations to the task content of jobs. Routine-task intensity is positively correlated with the average age across occupations. The estimated coefficient equals 0.34 and is statistically significant. It suggests that occupations, whose routine-task intensity is one standard deviation above the mean, have become 0.34 years older compared to the mean. The age increases in relatively routine-task intensive occupations seems to be driven by a falling employment share of workers below the age of 40 and a rising employment share of worker above 40 in these occupations. One interpretation of this result is that young workers shy away from these occupations, while older workers have no opportunity or incentive for mobility.

The estimated coefficient for the importance of abstract tasks on average occupational age is very small and statistically insignificant. However, the estimated coefficients for the two younger groups of workers are statistically significant and negative for the 16-24 age group and positive for the 25-39 age group. The relationship between the importance of abstract tasks and the age distribution of employment seems to be non-linear. Occupation that require more abstract tasks seem to have experienced an increase in the share of 25-39 year old workers and a decline in the share of very young (16-24 year old) and workers above 40 . The negative effect on the youngest group could be due to selection, which seems to be consistent with the negative coefficient for the educational level in the second row of Table 3. In addition, the group of 25-39 year old workers mostly applies human capital acquired during 
education, which gives them a comparative advantage in more abstract tasks (e.g., Weinberg, 2001).

The final rows with estimates in Table 3 report the coefficients of the effort-reward balance. This measure is a signal for job quality across the 96 occupations in our database (e.g., Siegrist et al., 2006). The estimated coefficients are all statistically insignificant, except for the negative estimate for the age group of 25-39 year old workers. Occupations with a relatively lower effort-reward balance seem to have seen a falling share of 25-39 year old workers. The point estimates are relatively small, implying that there is no strong job quality decline with age in this dimension once we control for changes in employment shares (estimated by $\beta_{1}$ ).

Overall, the following pattern emerges from this exercise. Occupations with relatively more unfavourable characteristics seem to have grown older. These are the occupations that seem to employ on average fewer high-skilled workers, demand more routine-intensive tasks and fewer abstract tasks, and are more exposed to foreign competition. The estimated effects for computerization and job quality point into the same direction but are economically small and statistically weak.

\section{Conclusion}

This paper has measured and interpreted changes in job opportunities of older workers in the Netherlands in the period 1996-2010. We have done so by investigating changes in the age composition of 96 three-digit occupations. On average, Dutch workers become almost three years older in this period. This is the consequences of an ageing workforce, a phenomenon observed in many countries. In the empirical analysis we have related differences in the changing age composition of occupations to changes in employment opportunities and measures of education, technological change, the task content of work and the quality of work.

We start our analysis from a standard human capital approach in which mobility becomes more costly when workers become older. This is the result of specific human capital and skills obsolescence among older workers. Hence, observing relatively older workers in declining occupations is a market outcome. Indeed, our estimates suggest that workers aged 40 and above are statistically significant more observed in occupations that are declining in terms of employment. In particular, we find that a one percentage point decline in 
employment is associated with an almost one year higher age in an occupation. If we list occupations on the rise and those in decline we obtain a pattern consistent with the findings in other countries. Growing occupations are high-skilled occupations and occupations with a larger share of abstract tasks, such as business professionals and architects, but also occupations complementary to high-skilled occupations, such as personal care occupations and salespersons. Occupations that have lost most in terms of employment shares are medium-skilled occupations, such as bookkeepers and office clerks. On average these occupations employ a larger share of older workers.

In the second part of the analysis we focus on the characteristics of occupations by developing measures of technological change, task content and job quality. The estimated coefficients suggest that ageing occupations are relatively more specialized in routine-task activities and more subject to offshoring. This worsens job opportunities for older workers and makes these occupations less attractive and less sustainable. At the same time, the effects of technological change (measured by computerization) and job quality do not seem to be different in the age dimension of occupations, once we control for changes in employment shares.

Although our analysis uses a simple approach to analysing the job opportunities for older workers, there seems policy relevance in our findings. The objective of governments is to extend the working life of citizens. The share of older workers has increased because of cohort effects and because of policies to provide incentives to postpone (early) retirement. These policies seem to be effective, because the share of older workers has increased in the Netherlands. At the same time we observe two developments that could raise potential problems to extending employment and employment opportunities. First, changes in job tasks and the effects of offshoring seem to hurt occupations with larger shares of older workers more than younger workers. This makes it hard to stay in the labour market because both technology and competition from abroad seem to lead to declining employment opportunities for older workers. Second, we observe these trends not only for the oldest group of workers (those aged 60-64) but also for the older prime-aged workers (aged 40-59). For this latter group, extending working life and postponing retirement might become difficult and unattractive. 


\section{References}

Acemoglu, D. \& Autor, D.H. (2011). Skills, tasks and technologies: Implications for employment and earnings. In: O. Ashenfelter, \& D. Card (Eds.), Handbook of labor economics (Vol. 4b, pp. 1043-1171).

Ahituv, A. \& Zeira, J. (2005). Technical progress and early retirement. Working Paper, The Hebrew University of Jerusalem, Jerusalem.

Altonji, J. \& Shakotko, R. (1987). Do wages rise with seniority? Review of Economic Studies, 54(3), 437-459.

Akcomak, I.S., Borghans, L. \& Ter Weel, B. (2011). Measuring and interpreting trends in the division of labour in the Netherlands. De Economist, 159(3), 435-482

Autor, D.H. \& Dorn, D. (2009). This job is "getting old": measuring changes in job opportunities using occupational age structure. American Economic Review, 99(2), 4551.

Autor, D.H. \& Dorn, D. (2013). The growth of low skill service jobs and the polarization of the U.S. labor market. American Economic Review, 103, forthcoming.

Autor, D.H., Levy, F. \& Murnane, R.J. (2002). Upstairs downstairs: computers and skills on two floors of a large bank. Industrial and Labor Relations Review, 55(3), 432-447.

Autor, D.H., Levy, F. \& Murnane, R.J. (2003). The skill content of recent technological change: an empirical investigation. Quarterly Journal of Economics, 118(3), 12791333.

Autor, D.H., Katz, L.F. \& Krueger, A.B. (1998). Computing inequality: have computers changed the labor market? Quarterly Journal of Economics, 113(4), 1169-1213.

Autor, D.H., Katz, L.F. \& Kearney, M.S. (2006). The polarization of the US labor market. American Economic Review, 96(2), 198-194.

Bartel, A.P. \& Sicherman, N. (1993). Technological change and retirement decisions of older workers. Journal of Labor Economics, 11(1), 162-183.

Becker, G.S. (1962). Investment in human capital: a theoretical analysis. Journal of Political Economy, 70(5), 9-49.

Ben-Porath, Y. (1967). The production of human capital and the life cycle of earnings. Journal of Political Economy, 75(4), 352-365.

Bettendorf, L., Van der Horst, A., Draper, N., Van Ewijk, C., De Mooij, R. \& Ter Rele, H. (2011). Ageing and the conflict of interest between generations. De Economist, 159(3), 257-278.

Borghans, L., Cörvers, F., Kriechel, B. \& Montizaan, R. (2007). Productiviteit, beloning en arbeidsmarktparticipatie van ouderen. ROA Report No. 2007/5, Maastricht University, Maastricht.

Borghans, L. \& Ter Weel, B. (2002). Do older workers have more trouble using computers than younger workers? Research in Labor Economics, 21, 139-173. 
Borghans, L. \& Ter Weel, B. (2006). The division of labour, worker organisation and technological change. Economic Journal, 116(509), F45-F72.

Broer, D.P. (2001). Growth and welfare distribution in an ageing society: an applied general equilibrium analysis for the Netherlands. De Economist, 149(1), 81-114.

De Hek, P. \& Van Vuuren, D. (2010). Are older workers overpaid? A literature review. Discussion Paper No. 165, CPB Netherlands Bureau for Economic Policy Analysis, The Hague.

Deelen, A.P. (2012). Wage-tenure profiles and mobility. De Economist, 160(2), 141-155.

Euwals, R., De Mooij, R. \& Van Vuuren, D. (2009). Rethinking retirement. Special Publication No. 80, CPB Netherlands Bureau for Economic Policy Analysis, The Hague.

Friedberg, L. (2003). The impact of technological change on older workers: evidence from data on computer use. Industrial and Labor Relations Review, 56(3), 511-529.

Gathmann, C. \& Schönberg, U. (2010). How general is human capital? A task-based approach. Journal of Labor Economics, 28(1), 1-49.

Goos, M. \& Manning, A. (2007). Lousy and lovely jobs: The rising polarization of work in Britain. Review of Economics and Statistics, 89(1), 118-133.

Goos, M., Manning, A. and Salomons, A. (2009). The polarization of the European labor market. American Economic Review, 99(2), 58-63.

Goos, M., Manning, A. and Salomons, A. (2010). Explaining job polarization: The roles of technology, globalization and institutions. Discussion Paper No. 1026, Centre for Economic Performance, London.

Groot, L. \& De Grip, A. (1991). Technological change and skill formation in the bank sector. Economics of Education Review, 10(1), 57-71.

Heckman, J.J. \& Scheinkman, J. (1987). The importance of bundling in a Gorman-Lancaster model of earnings. Review of Economic Studies, 54(2), 243-255.

Heijdra, B.J. \& Mierau, J. (2011). The individual life cycle and economic growth: an essay on demographic macroeconomics. De Economist, 159(1), 63-87.

Jovanovic, B. (1979a). Job matching and the theory of turnover. Journal of Political Economy, 87(5), 972-990.

Jovanovic, B. (1979b). Firm-specific capital and turnover. Journal of Political Economy, 87(6), 1246-1260.

Kamborouv, G. \& Manovskii, I. (2009). Occupational specificity of human capital. International Economic Review, 50(1), 63-115.

Kotlikoff, L.J. \& Gokhale, J. (1992). Estimating a firm's age-productivity profile using the present value of workers' earnings. Quarterly Journal of Economics, 107(4), 12151242. 
Lazear, E.P. (2009). Firm-specific human capital: a skill-weights approach. Journal of Political Economy, 117(5), 914-940.

Michaels, G., Natraj, A. \& Van Reenen, J. (2010). Has ICT polarized skill demand? Evidence from eleven countries over 25 years. Discussion Paper No. 987, Centre of Economic Performance, London.

Neal, D. (1995). Industry-specific human capital: evidence from displaced workers. Journal of Labor Economics, 13(4), 653-677.

Peracchi, F. \& Welch, F. (1994). Trends in labor force transitions of older men and women. Journal of Labor Economics, 12(2), 210-242.

Poletaev, M. \& Robinson, C. (2008). Human capital specificity: evidence from the Dictionary of occupational titles and displaced worker surveys, 1984-2000. Journal of Labor Economics, 26(3), 387-420.

Rosen, S. (1975). Measuring the obsolescence of knowledge. In: F.T. Juster (Ed.), Education, income and human behavior (pp. 199-232).

Saint-Paul, G. (2009) Does the welfare state make older workers unemployable? IDEI Working Paper No. 569, University Toulouse I, Toulouse.

Schils, T. (2005). Early retirement patterns in Europe: A comparative panel study. $\mathrm{PhD}$ Thesis, Tilburg University.

Siegrist, J., Wahrendorf, M., Von dem Knesebeck, O., Jurges, H. \& Borsch-Supan, A. (2006). Quality of work, well-being, and intended early retirement of older employeesbaseline results from the SHARE Study, European Journal of Public Health, 17(1), 62-68.

Ter Weel, B. (2012). Loonongelijkheid in Nederland stijgt. Policy Brief No. 2012/6, CPB Netherlands Bureau for Economic Policy Analysis, The Hague.

Vandenberghe, V. (2011). Introduction to De ECONOMIST special issue on "Ageing Workforces". De Economist, 159(2), 89-94.

Van Ours, J.C. (2009). Will you still need me when I'm 64? De Economist, 157(4), 441-460.

Van Ours, J.C. \& Stoeldraijer, L. (2011). Age, wage and productivity in Dutch manufacturing. De Economist, 159(2), 113-137.

Violante, G. (2002). Technological acceleration, skill transferability and the rise in residual inequality. Quarterly Journal of Economics, 117(1), 297-338.

Weinberg, B.A. (2001). Experience and technological adoption. Working Paper, Ohio State University, Columbus $(\mathrm{OH})$. 


\section{Appendix}

This appendix presents background information on the data sources we have used to construct the variables used in the analysis. Table A1 documents the variables and the way in which they are constructed. The final column shows the data source. Table A2 presents descriptive statistics of the variables.

\section{Table A1. Data sources and variable construction}

\begin{tabular}{|l|l|l|}
\hline Variable & Construction & Data source \\
\hline Employment (\%) & Employment share in total employment & EBB, 1996-2010 \\
\hline Age (years) & Mean age and classes by occupations & EBB, 1996-2010 \\
\hline Education (\%) & Share of tertiary workers in an occupation & EBB, 1996-2010 \\
\hline Computer (1-5) & Use of computers and computer systems & ONET, 2010 \\
\hline Offshoring & $\begin{array}{l}\text { Indicator developed in Akcomak, Borghans and Ter } \\
\text { Weel (2011) }\end{array}$ & $\begin{array}{l}\text { CBS, Input-output tables, } \\
1996-2005\end{array}$ \\
\hline Routine-task intensity & Ratio of technical to basic tasks & ONET 2010 \\
\hline Abstract-task intensity & $\begin{array}{l}\text { Sum of direction, control and planning tasks and } \\
\text { general education development and mathematical } \\
\text { tasks }\end{array}$ & DOT, 1991 \\
\hline Effort-reward & $\begin{array}{l}\text { Effort vs. reward as developed in Siegrist et al. } \\
(2006)\end{array}$ & SHARE, 2004 \\
\hline
\end{tabular}

Table A2. Descriptive statistics

\begin{tabular}{|c|c|c|c|c|}
\hline Variable & mean & st.dev. & $\min$. & $\max$ \\
\hline Employment (\%) & 1.01 & 1.13 & 0.03 & 5.66 \\
\hline Age (years) & 38.83 & 4.41 & 20.03 & 50.09 \\
\hline Education $(\%)$ & 29.19 & 33.05 & 0.00 & 99.08 \\
\hline Computer (1-5) & 3.15 & 0.91 & 1.30 & 4.92 \\
\hline Offshoring & 0.16 & 0.08 & 0.04 & 0.35 \\
\hline Routine-task intensity & 0.65 & 0.19 & 0.36 & 1.04 \\
\hline Abstract-task intensity & 6.12 & 4.47 & 0.04 & 17.28 \\
\hline Effort-reward & 0.85 & 0.15 & 0.48 & 1.31 \\
\hline
\end{tabular}


Table 1. Correlation matrix

\begin{tabular}{|l|r|r|r|r|r|r|l|l|}
\hline & $\begin{array}{l}\Delta \text { Mean } \\
\text { age }\end{array}$ & $\Delta$ Empl. & $\begin{array}{l}\text { High- } \\
\text { educ. }\end{array}$ & $\begin{array}{l}\text { Comp. } \\
\text { use }\end{array}$ & $\begin{array}{l}\text { Off- } \\
\text { shoring }\end{array}$ & $\begin{array}{l}\text { Routine } \\
\text { tasks }\end{array}$ & $\begin{array}{l}\text { Abstract } \\
\text { tasks }\end{array}$ & $\begin{array}{l}\text { Effort- } \\
\text { reward }\end{array}$ \\
\hline$\Delta$ Mean age & 1.000 & & & & & & & \\
\hline$\Delta$ Employment & $-\mathbf{0 . 2 6 9}$ & 1.000 & & & & & & \\
\hline High-educated & $-\mathbf{0 . 2 4 7}$ & 0.150 & 1.000 & & & & & \\
\hline Computer use & -0.160 & -0.030 & $\mathbf{0 . 6 5 1}$ & 1.000 & & & & \\
\hline Offshoring & $\mathbf{0 . 4 5 5}$ & $-\mathbf{0 . 2 6 6}$ & $\mathbf{- 0 . 4 9 4}$ & $\mathbf{0 . 3 4 0}$ & 1.000 & & & \\
\hline Routine tasks & $\mathbf{0 . 4 3 4}$ & -0.130 & $\mathbf{- 0 . 6 7 1}$ & $-\mathbf{0 . 6 4 2}$ & $\mathbf{0 . 7 0 5}$ & 1.000 & & \\
\hline Abstract tasks & -0.140 & 0.130 & $\mathbf{0 . 4 1 3}$ & $\mathbf{0 . 4 1 3}$ & $\mathbf{- 0 . 2 5 2}$ & $\mathbf{- 0 . 2 9 9}$ & 1.000 & \\
\hline Effort-reward & $\mathbf{0 . 2 6 0}$ & -0.060 & $-\mathbf{0 . 5 3 8}$ & $-\mathbf{0 . 5 0 0}$ & $\mathbf{0 . 5 1 1}$ & $\mathbf{0 . 5 4 1}$ & $-\mathbf{0 . 4 1 8}$ & 1.000 \\
\hline
\end{tabular}

Note: Bold numbers are significant at the 5 percent level $(p<0.05)$. The variables are defined in Table A.1 in the Appendix. 
Table 2. Occupations with the largest positive and negative employment changes

\begin{tabular}{|c|c|c|c|c|}
\hline Growing occupations & Growth & $\begin{array}{l}\text { Average } \\
\text { age }\end{array}$ & $\begin{array}{l}\text { Initial } \\
\text { share }\end{array}$ & ISCO \\
\hline Business professionals & 0.70 & 39.26 & 2.39 & 241 \\
\hline Personal care and related workers & 0.62 & 38.90 & 3.07 & 513 \\
\hline Business services agents and trade brokers & 0.55 & 36.43 & 0.90 & 342 \\
\hline Architects, engineers and related professionals & 0.51 & 41.06 & 2.14 & 214 \\
\hline Shop salespersons and demonstrators & 0.51 & 32.65 & 5.02 & 522 \\
\hline \multicolumn{5}{|l|}{ Declining occupations } \\
\hline Administrative associate professionals & -1.15 & 38.84 & 4.14 & 343 \\
\hline Other office clerks & -0.68 & 38.29 & 1.91 & 419 \\
\hline Secretaries and keyboard-operating clerks & -0.58 & 38.14 & 1.70 & 411 \\
\hline Electrical and electronic equipment mechanics and fitters & -0.47 & 37.10 & 0.94 & 724 \\
\hline Numerical clerks & -0.46 & 38.22 & 1.34 & 412 \\
\hline
\end{tabular}

Note: Growth and decline are defined as percent changes in employment shares between 1996-1999 and 20072010. 
Table 3. Estimation results (dependent variable: change in the mean age of an occupation or the share of workers in a certain age bracket within an occupation, 19962010)

\begin{tabular}{|c|c|c|c|c|c|}
\hline & $\Delta$ Age & $\Delta 16-24$ & $\Delta 25-39$ & $\Delta 40-59$ & $\Delta 60-64$ \\
\hline $\begin{array}{l}\Delta \text { Employment } \\
1996-2010 \\
\end{array}$ & $\begin{array}{r}-0.95 * * * \\
(0.34) \\
\end{array}$ & $\begin{array}{r}2.29 * * * \\
(0.83) \\
\end{array}$ & $\begin{array}{r}0.98 \\
(1.29) \\
\end{array}$ & $\begin{array}{r}-2.82 * \\
(1.56) \\
\end{array}$ & $\begin{array}{r}-0.45 \\
(0.34) \\
\end{array}$ \\
\hline \multicolumn{6}{|l|}{ Education } \\
\hline High-educated & $\begin{array}{r}-0.81^{*} \\
(0.45)\end{array}$ & $\begin{array}{l}-0.45 \\
(1.11)\end{array}$ & $\begin{array}{r}7.34 * * * \\
(1.55)\end{array}$ & $\begin{array}{r}-7.96 * * * \\
(1.91)\end{array}$ & $\begin{array}{r}1.06 * * \\
(0.43)\end{array}$ \\
\hline $\begin{array}{l}\Delta \text { Employment } \\
1996-2010\end{array}$ & $\begin{array}{r}-0.91 * * * \\
(0.34)\end{array}$ & $\begin{array}{r}2.31 * * * \\
(0.84)\end{array}$ & $\begin{array}{r}0.61 \\
(1.16)\end{array}$ & $\begin{array}{r}-2.41^{*} \\
(1.44)\end{array}$ & $\begin{array}{l}-0.50 \\
(0.33)\end{array}$ \\
\hline \multicolumn{6}{|l|}{ Technology } \\
\hline Computer use & $\begin{array}{r}0.07 \\
(0.14)\end{array}$ & $\begin{array}{l}-0.46 \\
(0.34)\end{array}$ & $\begin{array}{r}0.18 \\
(0.54)\end{array}$ & $\begin{array}{r}0.58 \\
(0.65)\end{array}$ & $\begin{array}{r}-0.30 * * \\
(0.14)\end{array}$ \\
\hline $\begin{array}{l}\Delta \text { Employment } \\
1996-2010\end{array}$ & $\begin{array}{r}-0.93 * * * \\
(0.35)\end{array}$ & $\begin{array}{r}2.13 * * * \\
(0.84)\end{array}$ & $\begin{array}{r}1.04 \\
(1.31)\end{array}$ & $\begin{array}{r}-2.62^{*} \\
(1.58)\end{array}$ & $\begin{array}{r}-0.55^{*} \\
(0.33)\end{array}$ \\
\hline Offshoring & $\begin{array}{r}0.25 \\
(0.15) \\
\end{array}$ & $\begin{array}{r}-0.79 * * \\
(0.36)\end{array}$ & $\begin{array}{r}-1.01 * \\
(0.57) \\
\end{array}$ & $\begin{array}{r}2.16 * * * \\
(0.66) \\
\end{array}$ & $\begin{array}{r}-0.36 * * \\
(0.15) \\
\end{array}$ \\
\hline $\begin{array}{l}\Delta \text { Employment } \\
1996-2010\end{array}$ & $\begin{array}{r}-0.79 * * \\
(0.35) \\
\end{array}$ & $\begin{array}{r}1.78 * * \\
(0.85) \\
\end{array}$ & $\begin{array}{r}0.34 \\
(1.32) \\
\end{array}$ & $\begin{array}{l}-1.44 \\
(1.54) \\
\end{array}$ & $\begin{array}{r}-0.68 * * \\
(0.34) \\
\end{array}$ \\
\hline \multicolumn{6}{|l|}{ Tasks } \\
\hline $\begin{array}{l}\text { Routine task } \\
\text { intensity }\end{array}$ & $\begin{array}{r}0.34 * * \\
(0.14) \\
\end{array}$ & $\begin{array}{l}-0.48 \\
(0.35) \\
\end{array}$ & $\begin{array}{r}-1.31 * * \\
(0.54) \\
\end{array}$ & $\begin{array}{r}1.75^{* * * *} \\
(0.64) \\
\end{array}$ & $\begin{array}{r}0.04 \\
(0.14) \\
\end{array}$ \\
\hline $\begin{array}{l}\Delta \text { Employment } \\
1996-2010\end{array}$ & $\begin{array}{r}-0.92 * * * \\
(0.33) \\
\end{array}$ & $\begin{array}{r}2.25 * * * \\
(0.83)\end{array}$ & $\begin{array}{r}0.86 \\
(1.26) \\
\end{array}$ & $\begin{array}{r}-2.66^{*} \\
(1.51)\end{array}$ & $\begin{array}{r}-0.45 \\
(0.34)\end{array}$ \\
\hline $\begin{array}{l}\text { Abstract task } \\
\text { intensity }\end{array}$ & $\begin{array}{l}-0.03 \\
(0.14) \\
\end{array}$ & $\begin{array}{r}-0.83 * * \\
(0.33) \\
\end{array}$ & $\begin{array}{r}1.27 * * \\
(0.51) \\
\end{array}$ & $\begin{array}{l}-0.42 \\
(0.64) \\
\end{array}$ & $\begin{array}{l}-0.02 \\
(0.14) \\
\end{array}$ \\
\hline $\begin{array}{l}\Delta \text { Employment } \\
1996-2010 \\
\end{array}$ & $\begin{array}{r}-0.95 * * * \\
(0.34) \\
\end{array}$ & $\begin{array}{r}2.50 * * * \\
(0.81)\end{array}$ & $\begin{array}{r}0.66 \\
(1.26) \\
\end{array}$ & $\begin{array}{r}-2.71 * \\
(1.57) \\
\end{array}$ & $\begin{array}{r}-0.44 \\
(0.34) \\
\end{array}$ \\
\hline \multicolumn{6}{|l|}{ Health } \\
\hline $\begin{array}{l}\text { Effort-reward } \\
\text { balance }\end{array}$ & $\begin{array}{r}0.13 \\
(0.15) \\
\end{array}$ & $\begin{array}{r}0.56 \\
(0.36) \\
\end{array}$ & $\begin{array}{r}-1.61 * * * \\
(0.54) \\
\end{array}$ & $\begin{array}{r}1.04 \\
(0.67) \\
\end{array}$ & $\begin{array}{r}0.02 \\
(0.15) \\
\end{array}$ \\
\hline $\begin{array}{l}\Delta \text { Employment } \\
1996-2010\end{array}$ & $\begin{array}{r}-0.96 * * * \\
(0.34)\end{array}$ & $\begin{array}{r}2.26 * * * \\
(0.83)\end{array}$ & $\begin{array}{r}1.07 \\
(1.24)\end{array}$ & $\begin{array}{r}-2.88^{*} \\
(1.55)\end{array}$ & $\begin{array}{r}-0.45 \\
(0.34)\end{array}$ \\
\hline Mean & $\begin{array}{r}2.78 \\
(2.06) \\
\end{array}$ & $\begin{array}{r}0.48 \\
(4.77)\end{array}$ & $\begin{array}{r}-12.36 \\
(6.60) \\
\end{array}$ & $\begin{array}{r}8.61 \\
(8.37) \\
\end{array}$ & $\begin{array}{r}3.30 \\
(1.98) \\
\end{array}$ \\
\hline
\end{tabular}

Note: $N=96 . * * * p<0.01, * * p<0.05, * p<0.10$. Each column corresponds to a separate OLS regression of the outcome variable at the top of the column on control variables, change in the occupation's share in total employment and a constant. Standard errors are reported in parentheses. 
Figure 1. Age composition of the Dutch workforce, 1996-2010

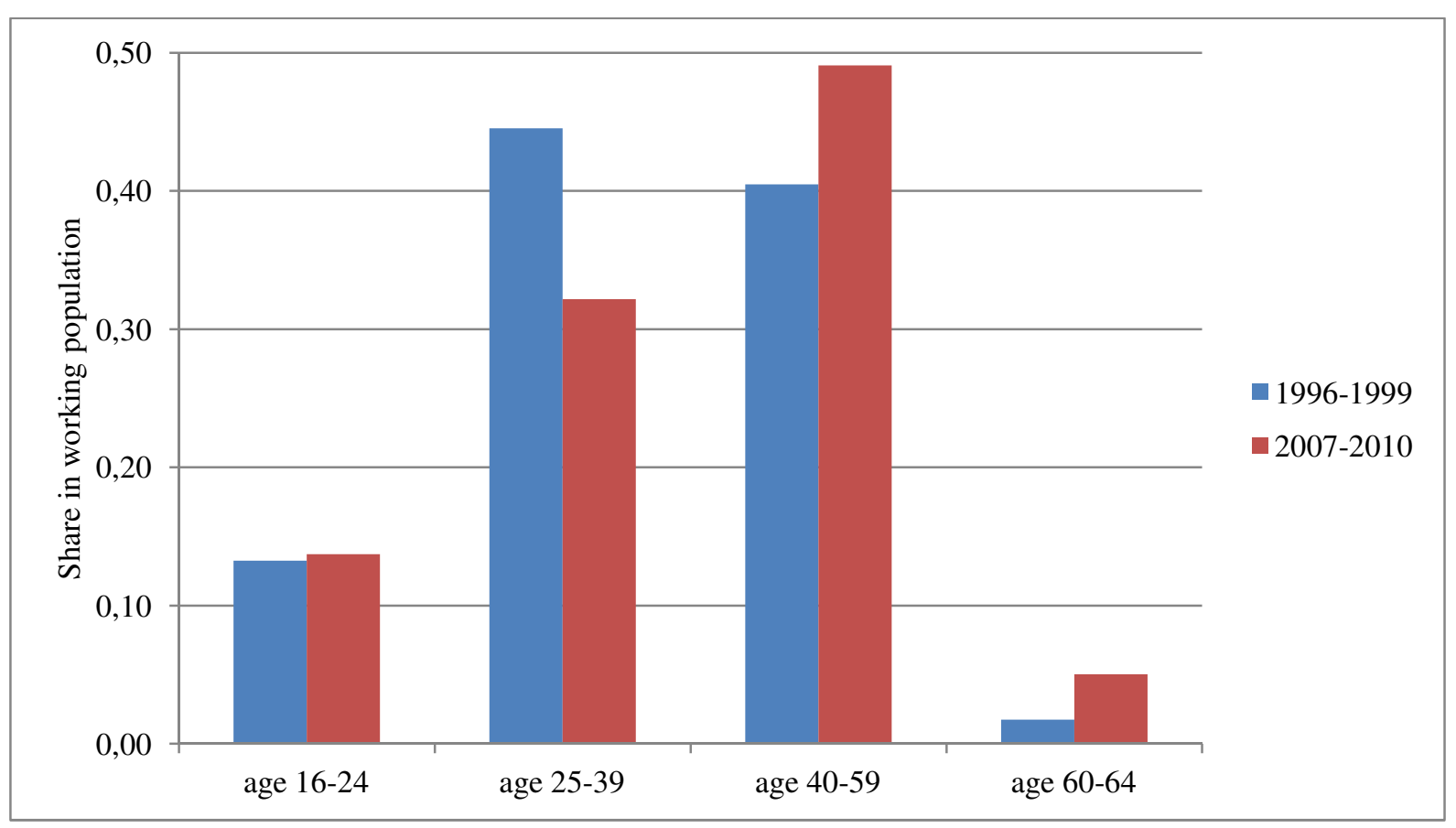


Figure 2. Changes in employment shares of shirking and growing occupations by age class

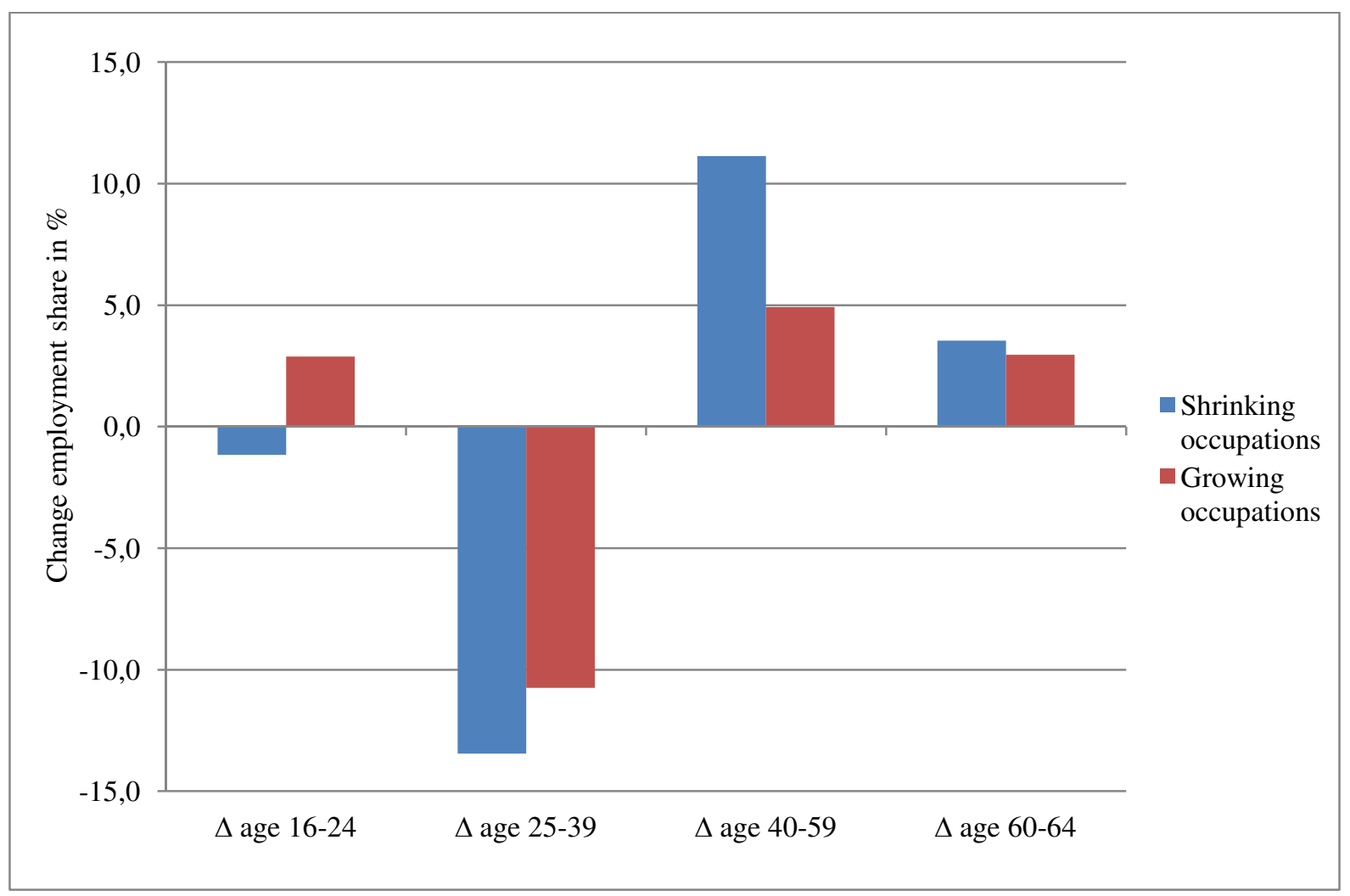


Figure 3. Changes (1996-2010) in the average age composition of occupations and employment shares

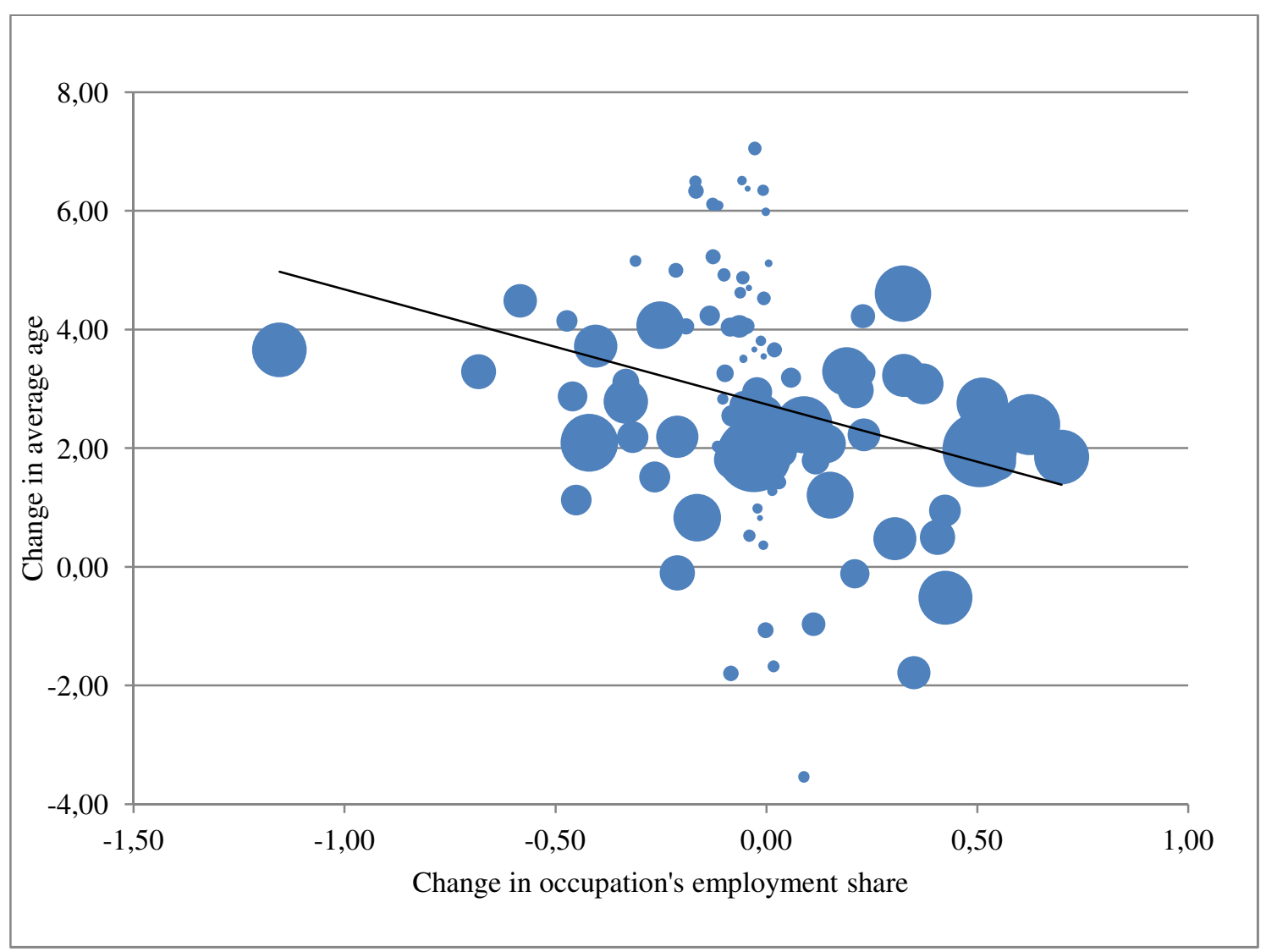


Figure 4. Changes (1996-2010) in the average age composition of occupations and technology, tasks and health indicators
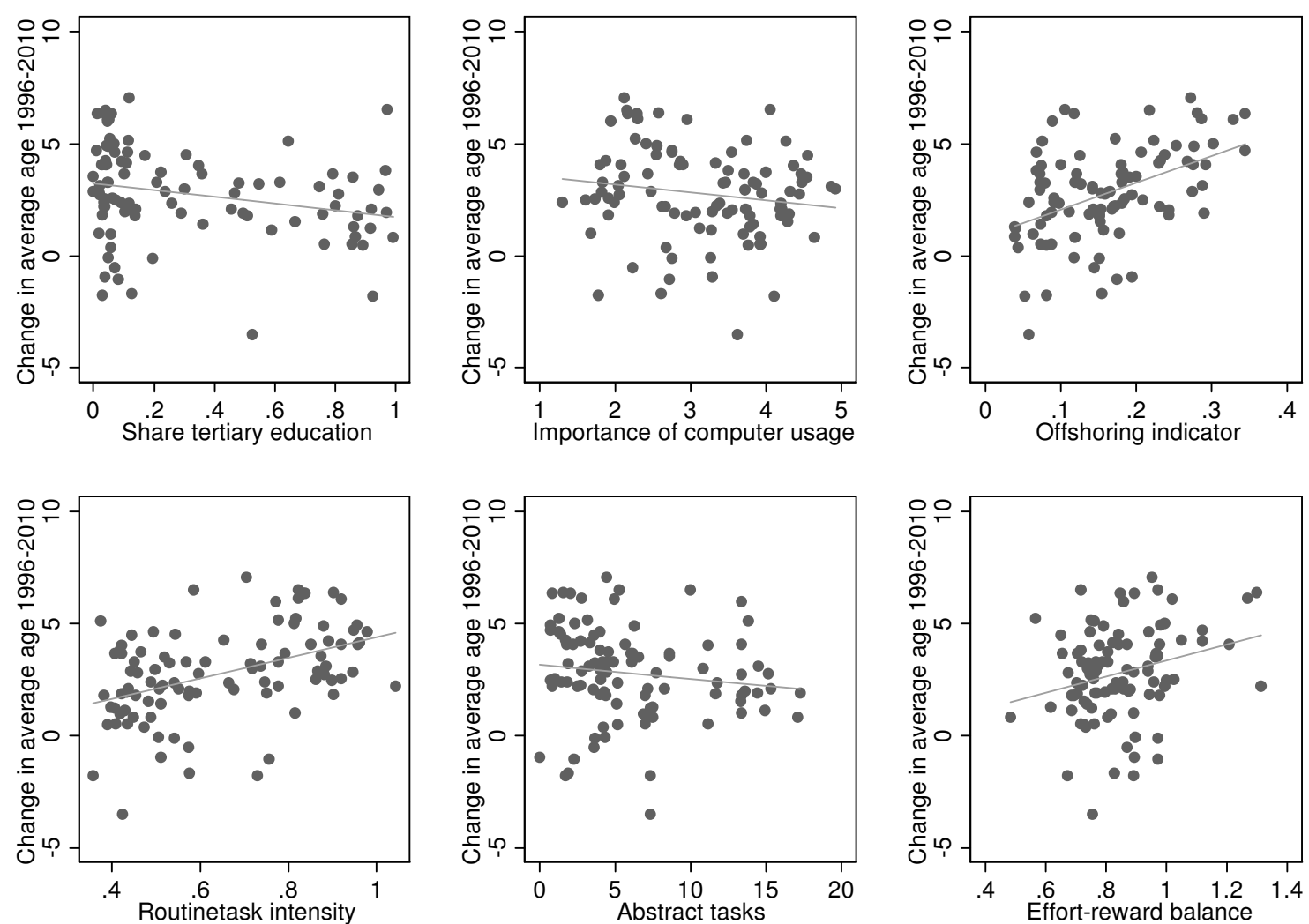